\title{
Some Observations on Four Probable Middle Caddo Period Cemeteries in Camp and Upshur Counties, Northeast Texas
}

Robert L. Turner Jr. Unknown

Follow this and additional works at: https://scholarworks.sfasu.edu/ita

Part of the American Material Culture Commons, Archaeological Anthropology Commons, Environmental Studies Commons, Other American Studies Commons, Other Arts and Humanities Commons, Other History of Art, Architecture, and Archaeology Commons, and the United States History Commons

Tell us how this article helped you.

This Article is brought to you for free and open access by the Center for Regional Heritage Research at SFA ScholarWorks. It has been accepted for inclusion in Index of Texas Archaeology: Open Access Gray Literature from the Lone Star State by an authorized editor of SFA ScholarWorks. For more information, please contact cdsscholarworks@sfasu.edu. 
Some Observations on Four Probable Middle Caddo Period Cemeteries in Camp and Upshur Counties, Northeast Texas

\section{Creative Commons License}

\section{(c) (1) \&}

This work is licensed under a Creative Commons Attribution-NonCommercial 4.0 International License 


\title{
Some Observations on Four Probable Middle Caddo Period Cemeteries in Camp and Upshur Counties, Northeast Texas
}

\author{
Robert L. Turner
}

In this paper, I discuss probable Middle Caddo period ceramic vessels and other artifacts from cemeteries at the Rumsey (41CP3), Harold Williams (41CP10), Graydon Adkins \#1 (41UR21), and Graydon Adkins \#2 (41UR17) sites in Camp and Upshur counties (Figure 1).

\section{Rumsey Site (41CP3)}

In the late 1930s or early 1940s, and apparently for several years after that, Greasy Creek would leave its banks during floods and uncover prehistoric Caddo graves with their attendant artifacts. The artifacts I discuss were collected by Mr. Rumsey, the landowner.

Several of the Rumsey site pottery vessels were purchased by $\mathrm{H}$. Perry Newell for the University of Texas, and are now at the Texas Archeological Research Laboratory in Austin. In 1948, I purchased the artifacts that Mr. Rumsey had at that time. This included 53 ceramic vessels, most of Titus phase types. However, among these pots were several of probable Middle Caddoan age, including bottles of Hickory Fine Engraved, Haley Engraved, and early Ripley Engraved-like, as well as two Handy Engraved-like widehandled bowls and a platform pipe (Figure 2). These artifacts must come from several graves at the Rumsey site.

\section{Harold Williams Site (41CP10)}

During the mid-1940s, Dry Creek overflowed its banks and uncovered a number of Titus phase graves at what is labeled the Harold Williams site. The associated ceramics were collected by Mr. Albert Hilton, the tenant, and by 1948 he had disposed of them to various unknown parties. I made surface collections at the site for several years, and in the 1950s Ralph Nicholas, Ed German, and I excavated 19 graves at Harold Williams.

In the spring of 1967, Ricky Williams, the son of the landowner Harold Williams, found a ceramic bottle with engraved rattlesnakes (Figure 3), two other small bowls (Figure 4), and a stone earspool (Figure 5e), in a new wash in freshly plowed ground. The Williams' notified me of the find. The Texas Archeological Society (TAS) happened to be looking for a site to work on for its 6th Field School, and the Harold Williams site was selected after a site visit by the TAS search committee (Kathleen Gilmore, C. A. Smith, and Paul Lorrain).

The engraved rattlesnake bottle (at least $18 \mathrm{~cm}$ in height) was well-fired, with no apparent temper, and was a chocolate-brown color. The straight bottle neck was decorated with four rocker-like lines, and the engraved rattlesnake motif was filled with hematite.

During the course of the Field School, Area A, where the snake-adorned bottle was found, was excavated with E. Mott Davis as area supervisor. At the location where the bottle had been found, a fragment of a small undecorated bowl was unearthed that matched one of the bowls found by Ricky Williams. Prior to the Field School, a platform pipe (with an upturned hand supporting the bowl) was found in the same area.

About $5 \mathrm{~m}$ south of this disturbed burial, a second grave was found on the west side of the wash. No skeletal remains were present, only a tight cluster of six small pottery vessels 


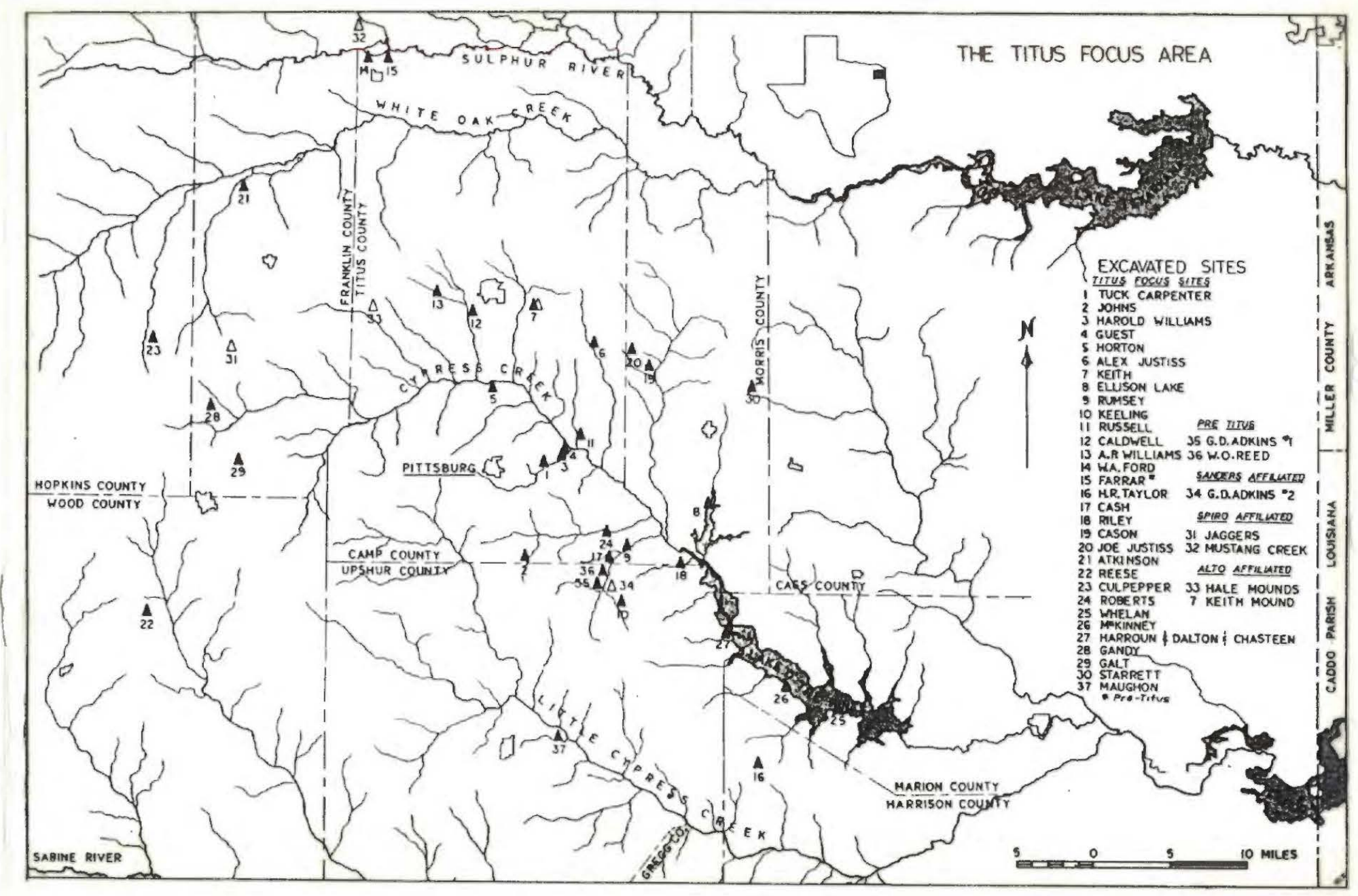

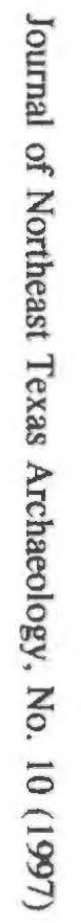

Figure 1. Excavated Sites in the Titus Focus Area (from Turner 1978). 


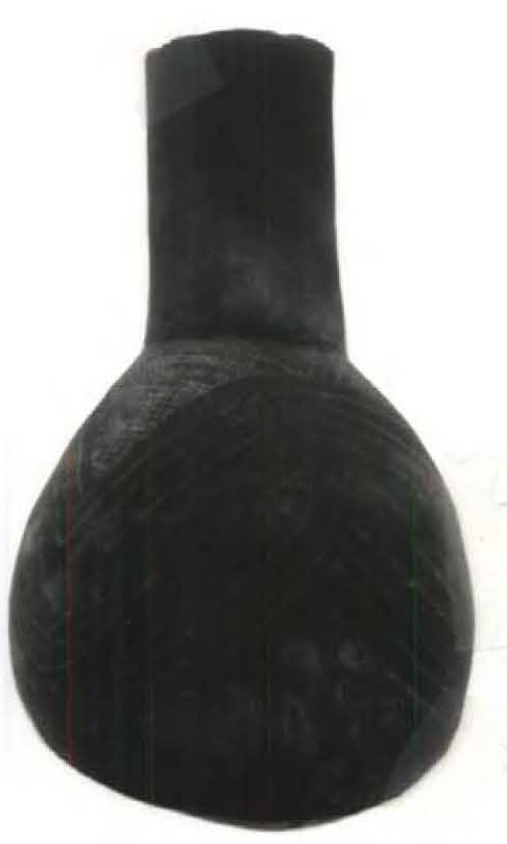

A

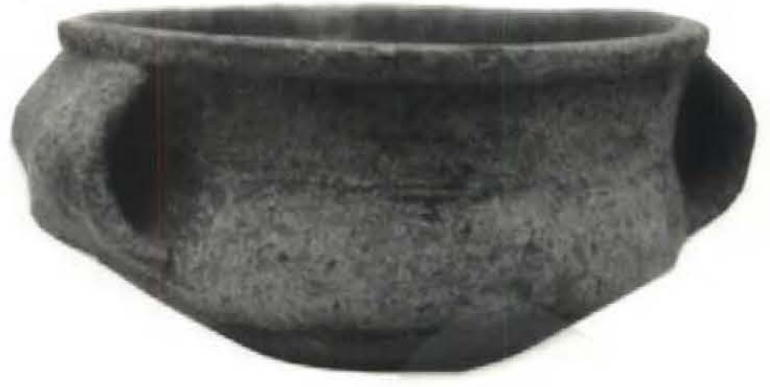

C

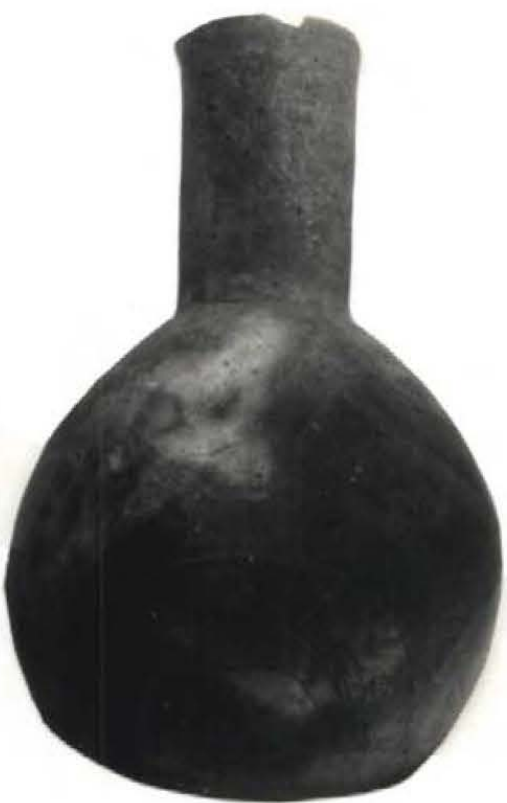

B

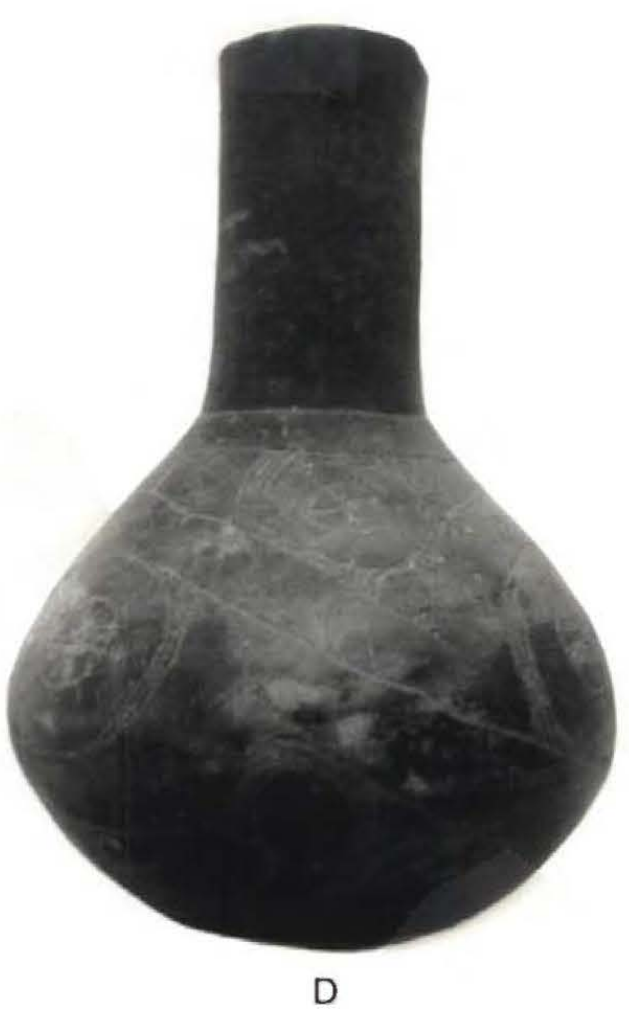

Figure 2. Rumsey Site vessels. 

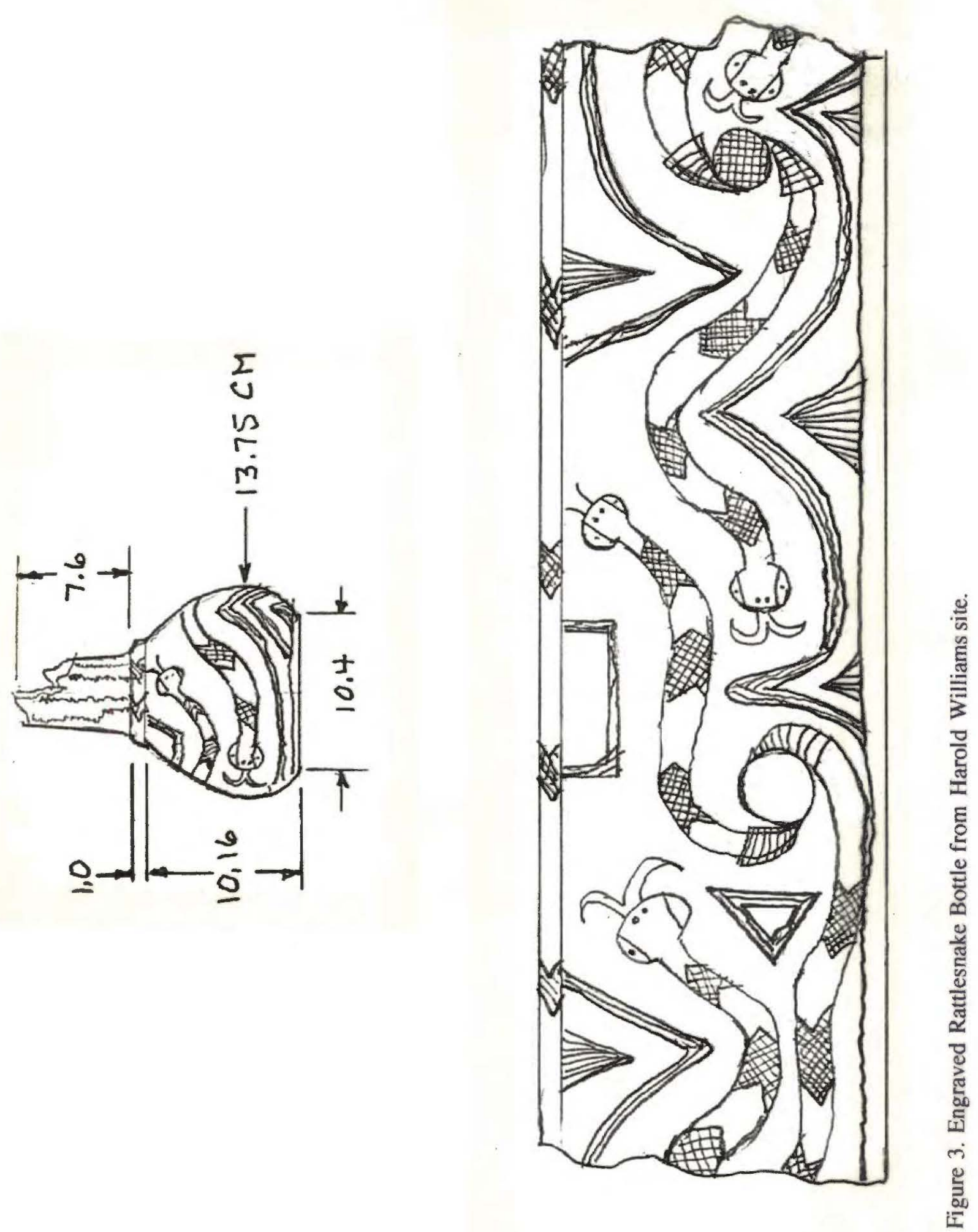


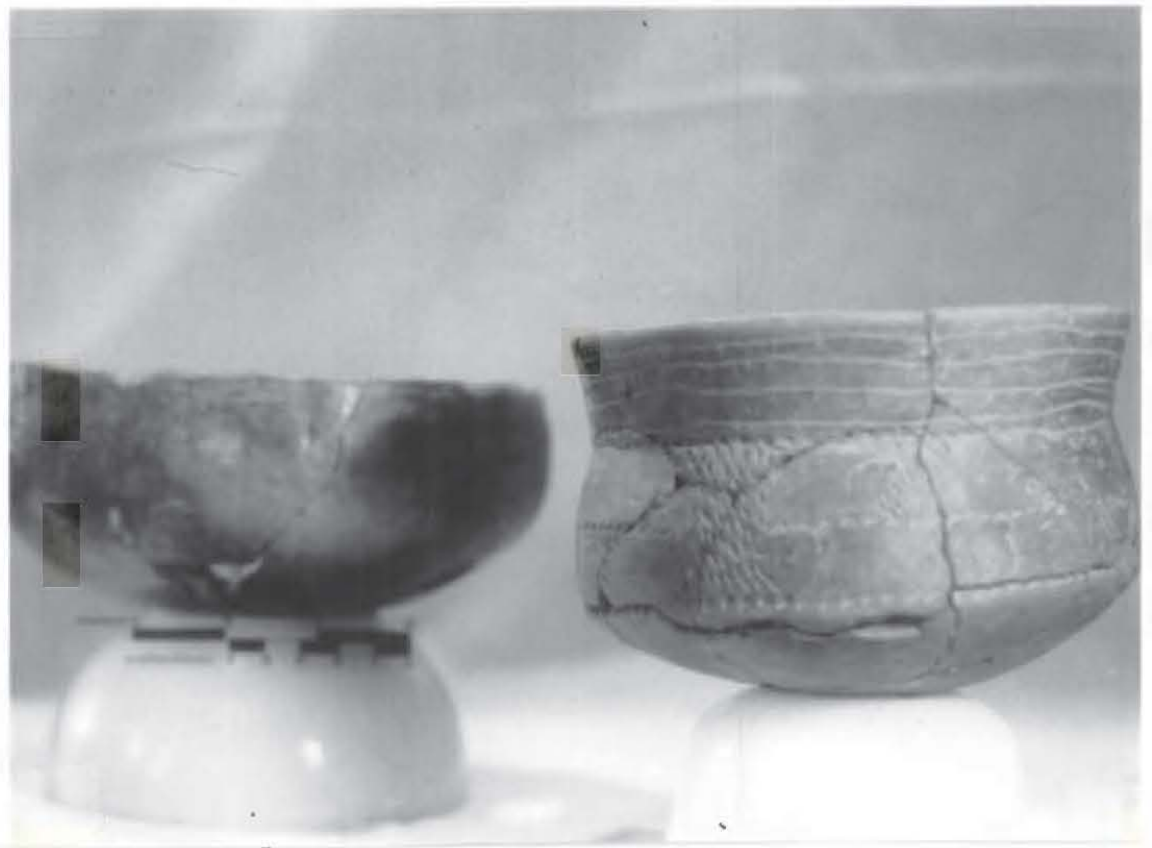

Figure 4. Two Bowls found in Association with the Engraved Rattlesnake Bottle at the Harold Williams site. 


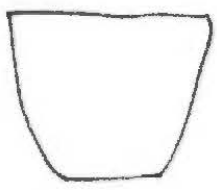

$A$

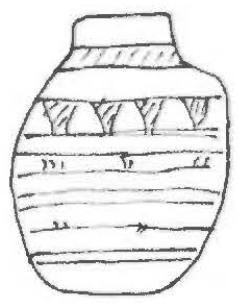

C

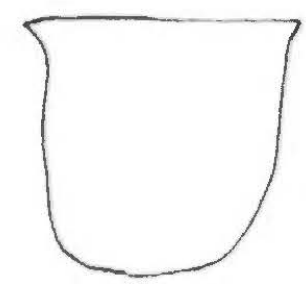

$B$

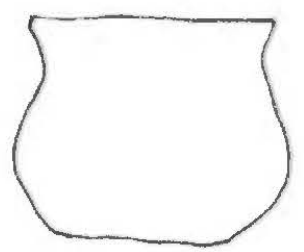

$D$

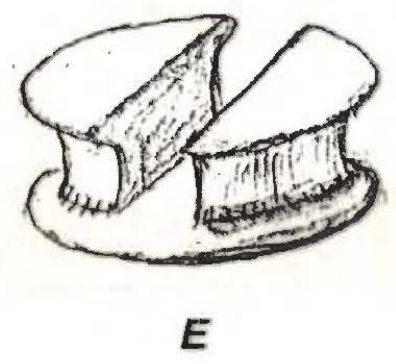

Figure 5. Ceramic Vessels and Stone Earspool from the Harold Williams site: a, plain conical bowl $(6.4 \mathrm{~cm}$ in height $)$; b, plain jar $(11.2 \mathrm{~cm}$ in height); $c$, engraved bottle $(12 \mathrm{~cm}$ in height); d, plain jar (10 cm in height); e, earspool. The earspool is $1.9 \mathrm{~cm}$ in width and $1.3 \mathrm{~cm}$ in thickness. 
(Figure 6). A punctated-appliqued-and brushed pot was identified as Pease BrushedIncised by J. Ned Woodall, the Field School Archeologist. The remaining five vessels included two small conical bowls, a small jar, a bottle with a shortened and resmoothed neck with light engraving (with a non-Titus phase design), and a small shouldered bowl. One possible Alba point was lying near these vessels, but it is unknown if it was a deliberately placed grave good.

In summary, both graves contained several small plain jars or bowls (see Figure 5a-d). In the wash area--probably the location of the engraved bottle with the rattlesnake motif--was found the platform pipe and about two-thirds of a small probable Pease Brushed-Incised jar.

\section{Graydon Adkins \#1 (41UR21)}

This Caddo site was excavated by Ed German and Ralph Nicholas of Daingerfield in early 1958. As opposed to the simple graves at the Harold Williams site, Grave 1 at Graydon Adkins \#1 contained 14 vessels (Figure 7 illustrates the range of vessels with Grave 1), two napkin-ring earspools, and six stemmed arrow points. Other graves also contained a number of vessels: Grave 3 had seven pots (Figure 8); Grave 4 contained eight vessels (Figure 9), including an eared bowl with an engraved rattlesnake design (see Figure 9e); and Grave 5 had 13 vessels (Figure 10).

Not all of the burial goods were available for the author to record, unfortunately. However, there were no large cooking pots or carinated bowls. Only one vessel had an orifice diameter as much as $30 \mathrm{~cm}$ in diameter, and this had a red slip and a trade vessel shape.

\section{Graydon Adkins \#2 (41UR17)}

In April and May 1958, Nicholas, German, and the author excavated eight burials at the Graydon Adkins \#2 site (Figure 11). All the graves were supine, and based on preserved skeletal remains, the people were apparently buried with their feet to the west as in the later Titus phase graves (Turner 1978). The graves contained between two and seven ceramic vessels (Figures 12-18), with one grave having two vessels; four graves contained three vessels; one grave had four vessels; and two other graves had seven vessels each.

The predominant vessel shapes at Graydon Adkins \#2 were small simple jars and undecorated bowls, but two conical bowls and a tapered neck bottle (of Early Caddoan form) were also in the collection (Figure 19). Other grave goods included a few well-made arrow points and a platform pipe.

\section{Summary}

There are similarities as well as differences between these sites in the kinds of artifacts found with the burials. The bottles and Handy Engraved-like vessels from the Rumsey site may date earlier than the Middle Caddoan period, or carryovers into the Middle Caddoan period. The Harold Williams and Graydon Adkins \#2 sites are similar in the groupings of grave goods, the small size and simplicity of the vessels, the addition of platform pipes, and the occurrence of a finely made vessel or two.

The Graydon Adkins \#1 site is comparable to Graydon Adkins \#2 and Harold Williams in the general size of the vessels included as grave offerings. Another similarity between them 


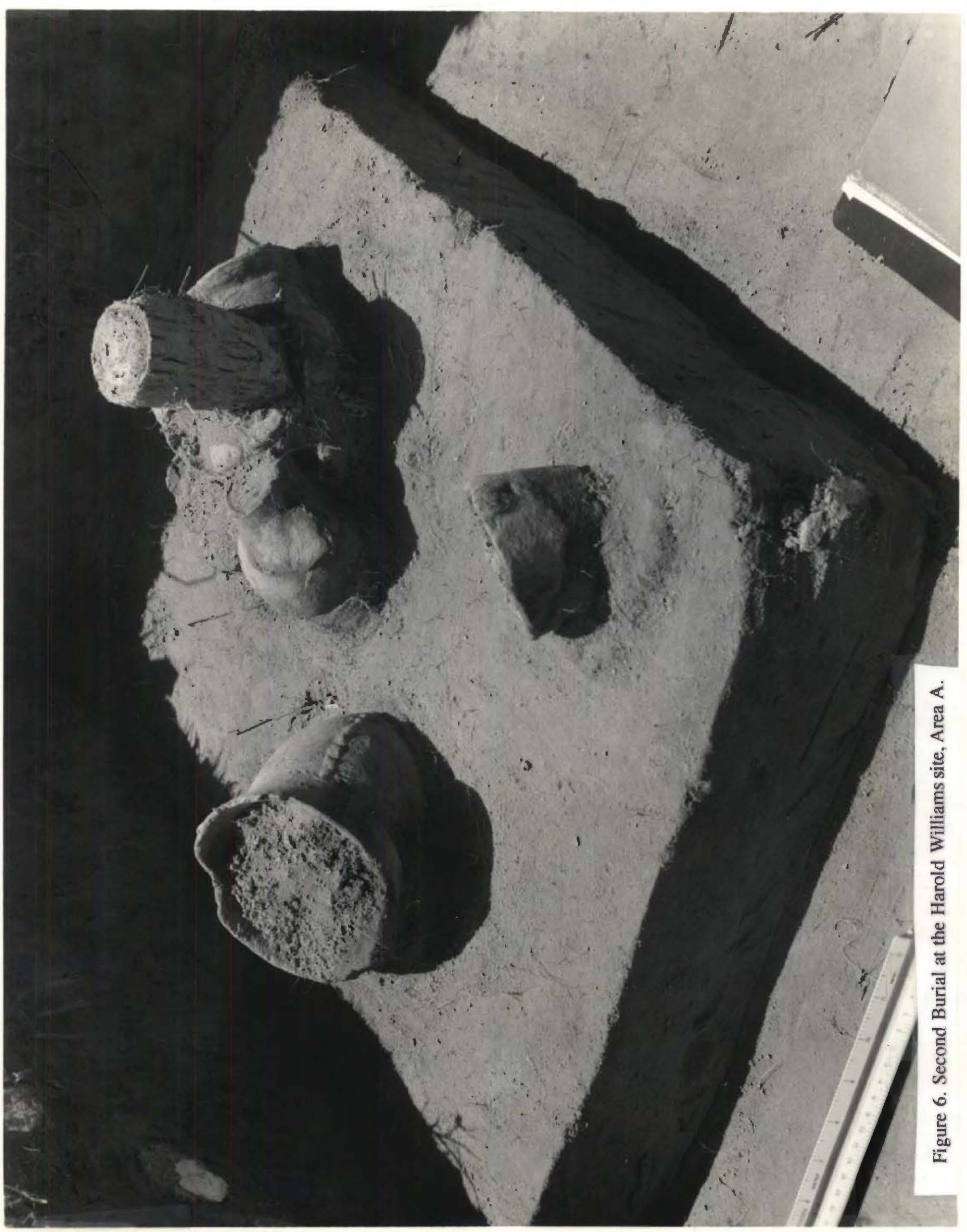




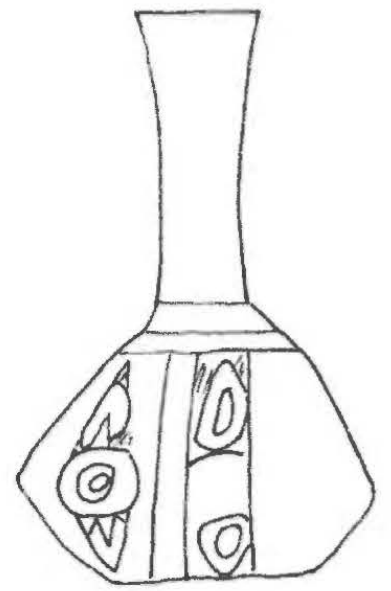

$A$

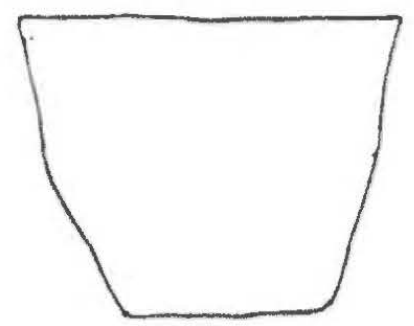

$D$

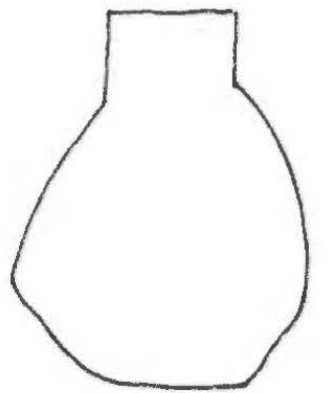

$B$
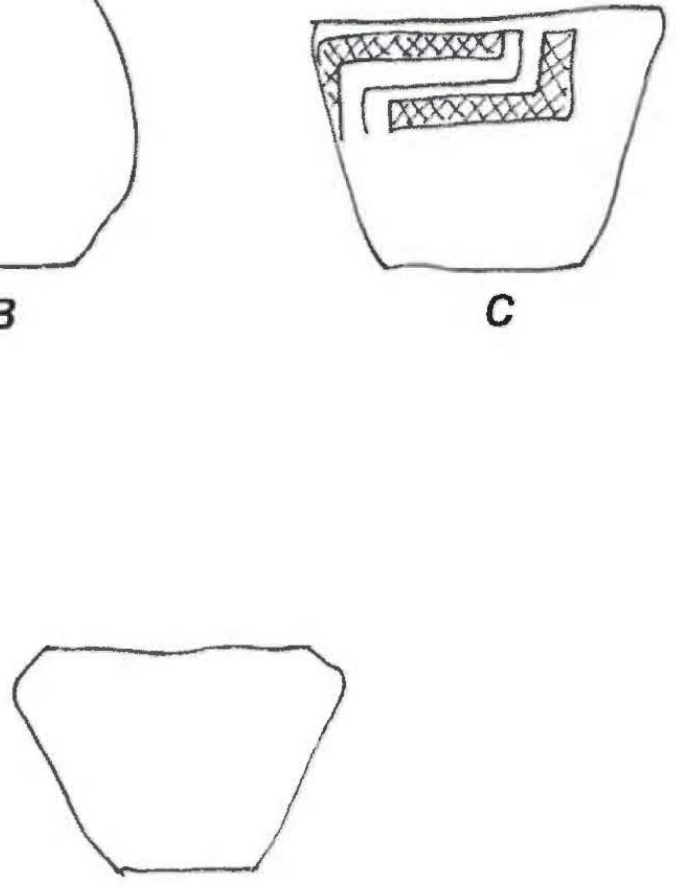

$E$

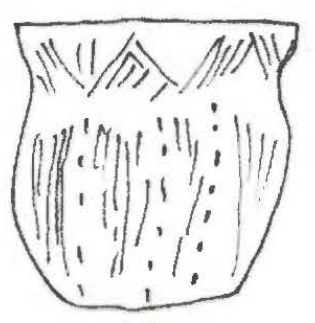

G

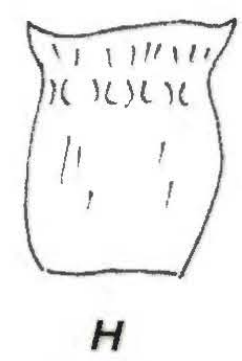

Figure 7. Ceramic Vessels from Burial 1, Graydon Adkins \#1 site: a, Vessel 2, engraved bottle (25 cm in height); b, Vessel 5 (24.3 cm in height); c, Vessel 4, engraved bowl $(9 \mathrm{~cm}$ in height); d, Vessel 7, plain bowl (14 cm in height); e, Vessel 1, plain red slipped bowl with scalloped lip (18 cm in height); $\mathrm{f}$, Vessel 9, incised-pinched jar (16.8 $\mathrm{cm}$ in height); g, Vessel 6, incised-punctated jar (11.5 cm in height); h, Vessel 13, pinchedbrushed jar $(11.5 \mathrm{~cm}$ in height). 


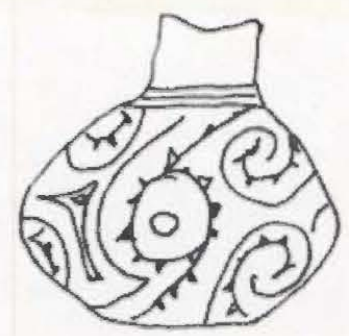

$\boldsymbol{A}$

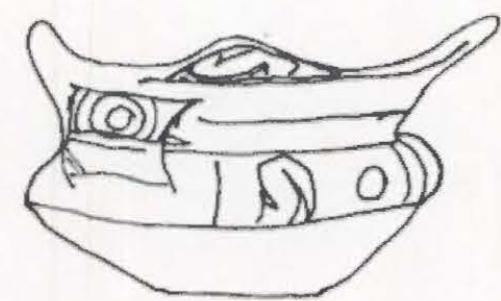

B

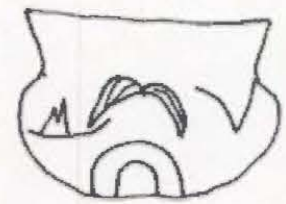

C

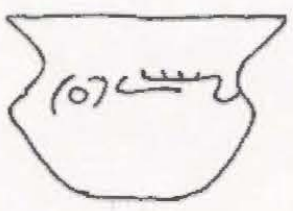

$D$

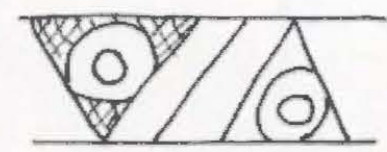

$E$

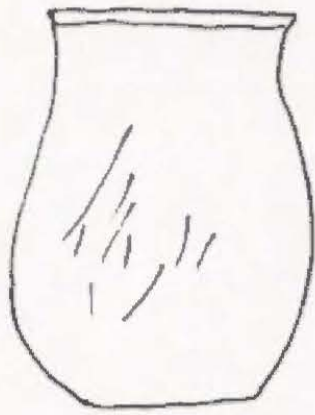

$\boldsymbol{F}$

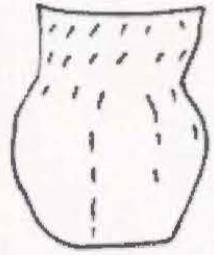

G

Figure 8. Ceramic Vessels from Burial 3, Graydon Adkins \#1 site: a, Vessel 4, engraved bottle; $b$, Vessel 5 , engraved compound bowl with handles $(20 \mathrm{~cm}$ in height $)$; $c$, Vessel 1 , engraved bowl ( $9 \mathrm{~cm}$ in height); d, Vessel 3 , engraved compound bowl $(8.2 \mathrm{~cm}$ in height); e, engraved motif on Vessel 2, carinated bowl; f, Vessel 7, brushed jar (14.7 $\mathrm{cm}$ in height); $\mathrm{g}$, Vessel 6 , punctated jar $(20.5 \mathrm{~cm}$ in height). 


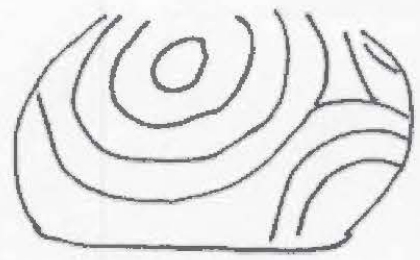

$A$

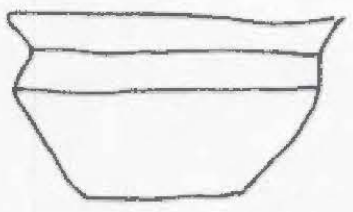

B

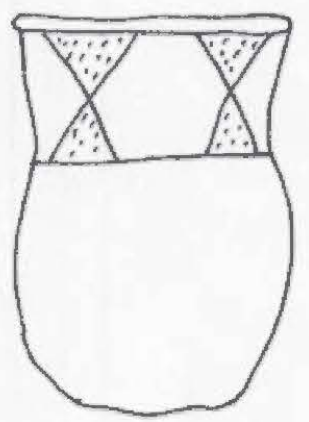

D

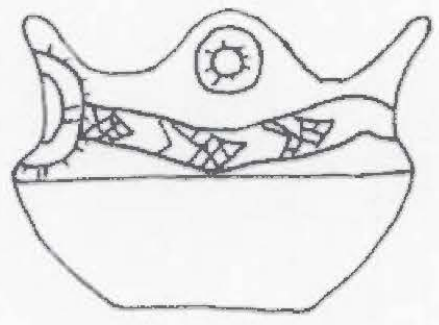

E

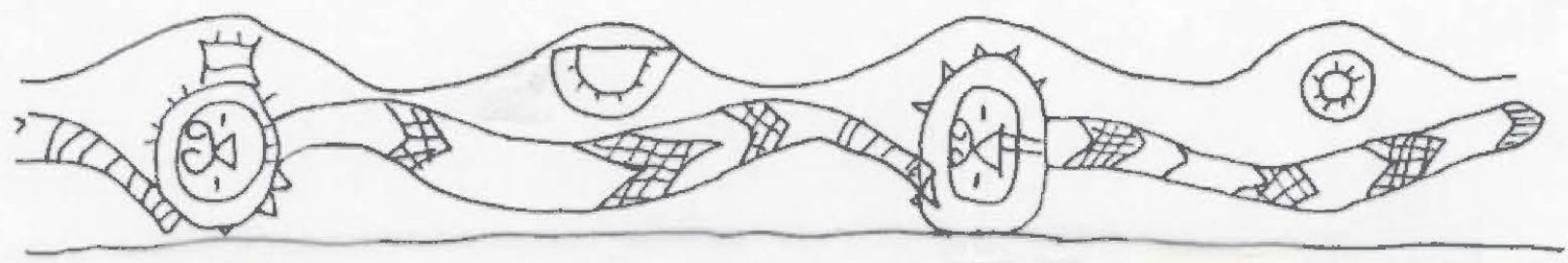

Figure 9. Ceramic Vessels from Burial 4, Graydon Adkins \#I site: a, Vessel 3, engraved bottle (21 cm in height); b, Vessel 8, engraved compound bowl; c, Vessel 7, plain bowl ( 9 $\mathrm{cm}$ in height); d, Vessel 1, incised-punctated jar (23 cm in height); e, Vessel 5 , engraved compound bowl with rattlesnake motif (10 cm in height). 


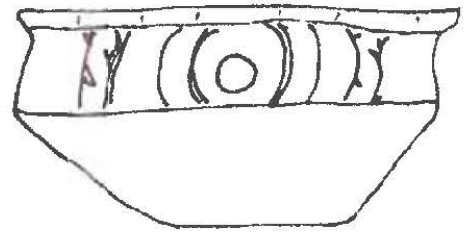

$\boldsymbol{A}$

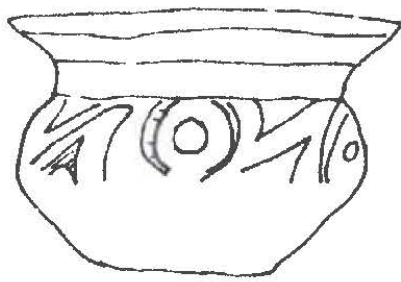

B

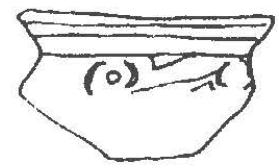

C

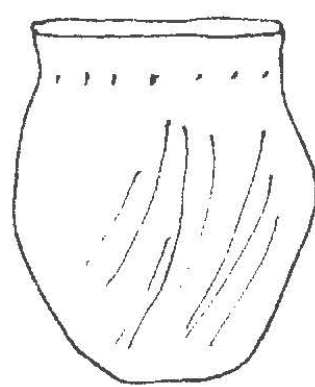

$\boldsymbol{D}$

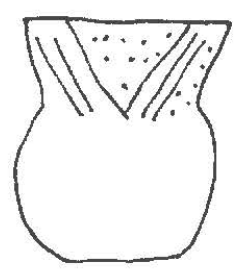

$E$

Figure 10a. Ceramic Vessels from Burial 5, Graydon Adkins \#1 site: a, Vessel 4, engraved carinated bowl (13.4 cm in height); b, Vessel 13, engraved compound bowl $(10.8 \mathrm{~cm}$ in height); $\mathrm{c}$, Vessel 2, engraved compound bowl (6.4 $\mathrm{cm}$ in height); d, Vessel 10 , punctated-brushed jar $(19.2 \mathrm{~cm}$ in height $)$; e, Vessel 3, punctated-incised jar $(12.8 \mathrm{~cm}$ in height). 


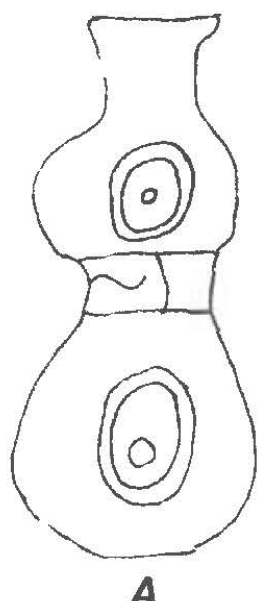

A

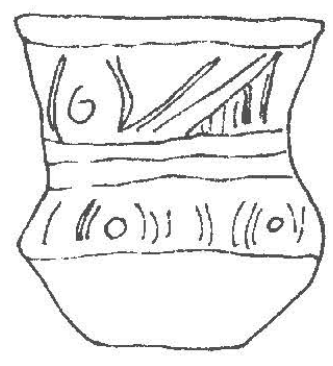

B

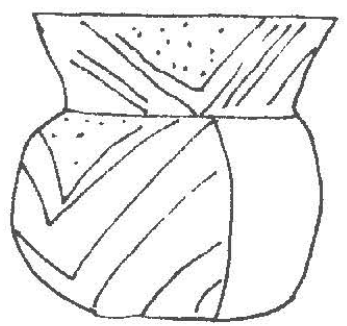

C

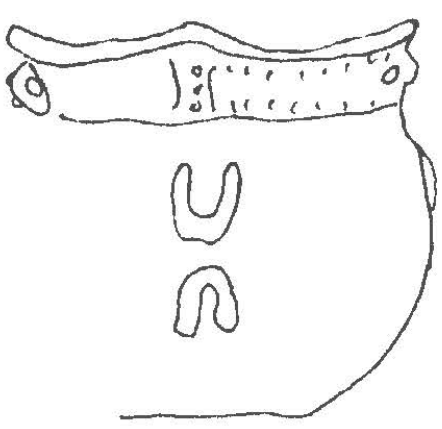

$D$

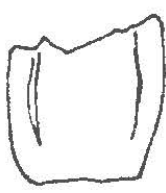

$E$

Figure 10b. Ceramic Vessels from Graydon Adkins \#1 site: a, engraved compound bottle (23 $\mathrm{cm}$ in height); $b$, engraved compound bowl ( $9 \mathrm{~cm}$ in height); $\mathrm{c}$, incised-punctated jar (12.8 $\mathrm{cm}$ in height); d, punctated-appliqued jar (14.1 cm in height): e, broken appliqued jar ( $9 \mathrm{~cm}$ in height). 


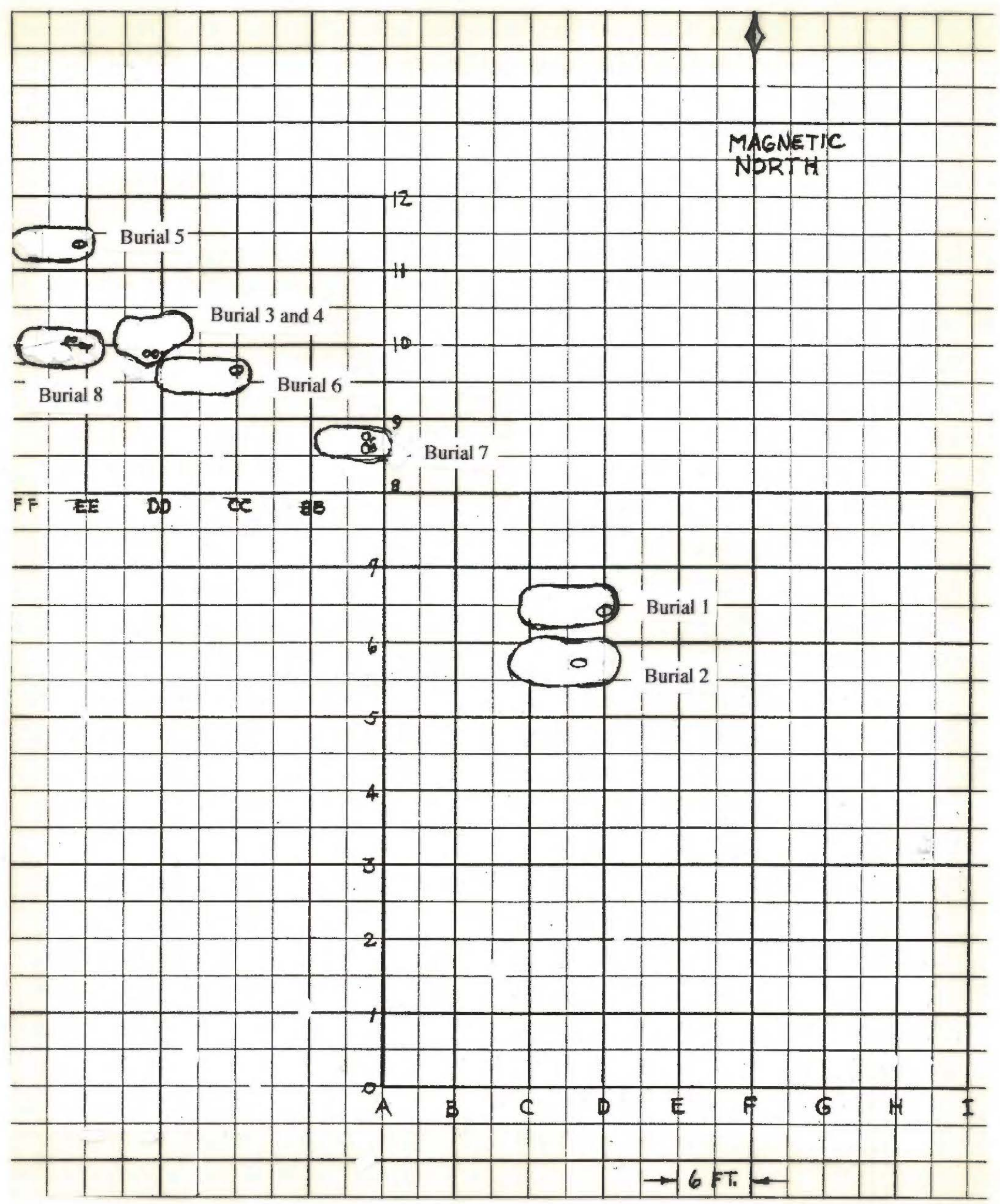

Figure 11. Excavations and Burials 1-8 at the Graydon Adkins \#2 site. 


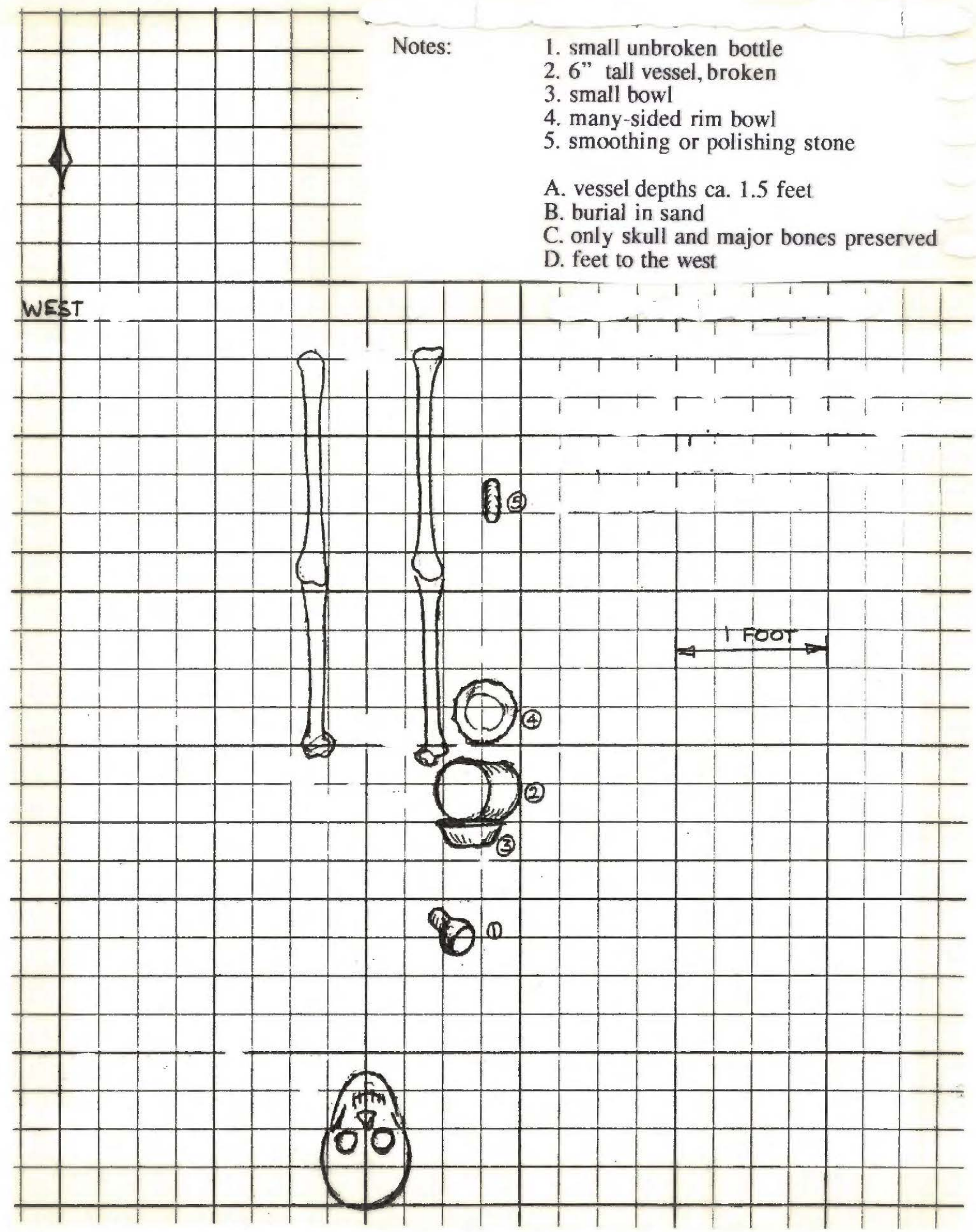

Figure 12. Burial 1, Graydon Adkins \#2 site. 


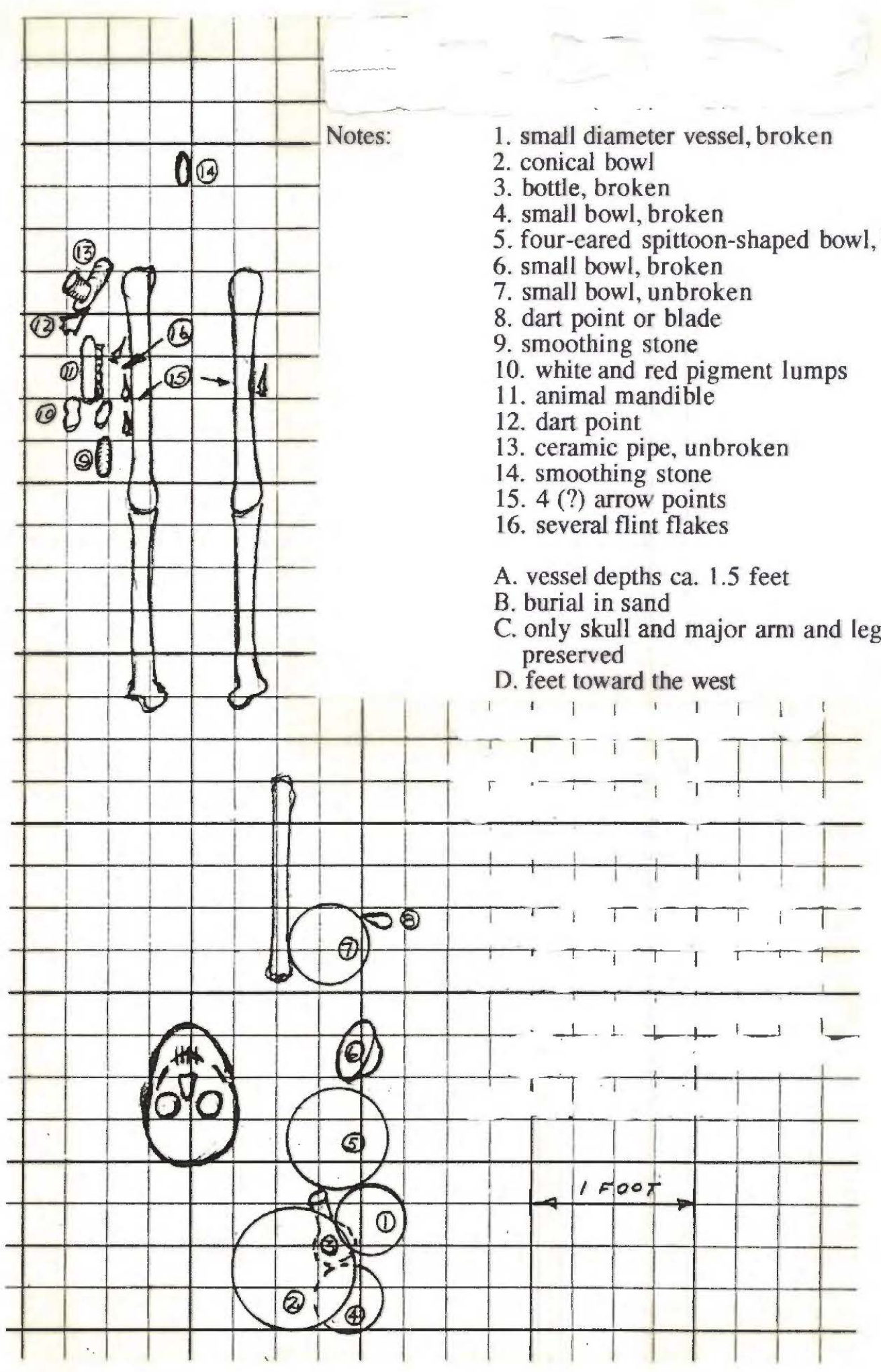

Figure 13. Burial 2, Graydon Adkins \#2 site. 
Notes:

Burial 3: $\quad$ 1. whole vessel, 1.5 feet bs

2. broken vessel, 1.5 feet bs

3. broken vessel, 1.5 feet bs

4. arrow point, 8 inches bs

5. animal tooth (deer?)

Burial 4: $\quad$ 1. broken vessel, 1 foot bs

2. vessel base and lower body, 14 inches bs

3. 2 or 3 human teeth in jaw fragment

4. 2 or 3 human teeth in jaw fragment

A. only skull and jaw fragments preserved

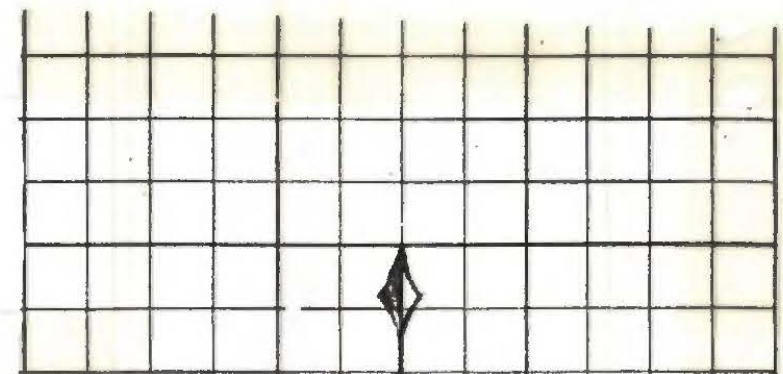

jaw fragments preserved t

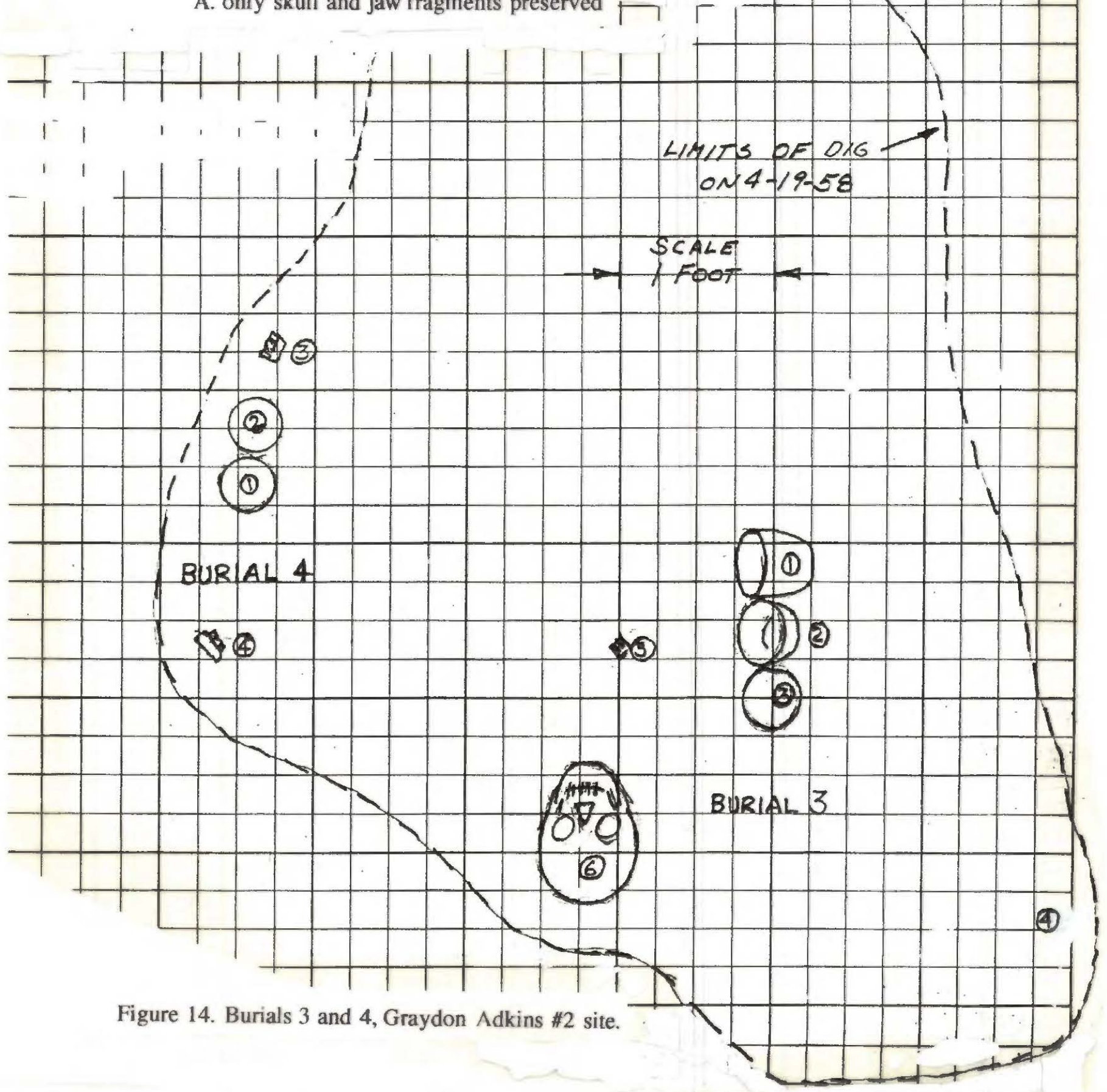


Notes: $\quad$ 1. whole vessel

2. vessel apparently broken when discovery hole was dug

3. whole bottle

4. whole bowl

5. broken abrading stone

A. skull 23 inches bs, while leg bones ranged from $17-23$ inches bs

B. feet oriented $20^{\circ} \mathrm{W}$ of $\mathrm{N}$
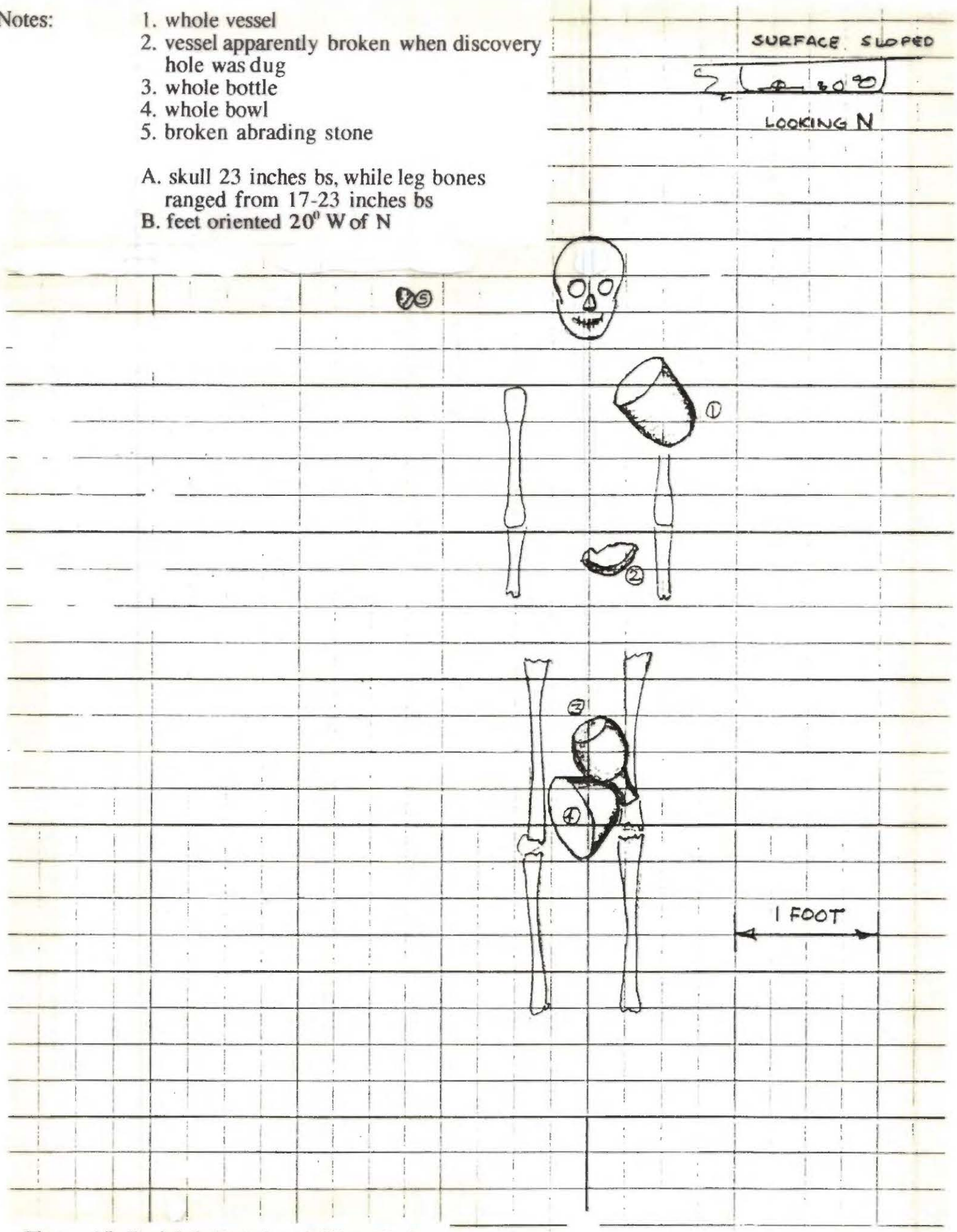

Figure 15. Burial 5, Graydon Adkins \#2 site. 
Notes: $\quad 1-2$. vessel fragments; may be from 1 vessel

3-8. cluster of six small bowls

9. whole bottle

10. small Gary point just above 1-2.

A. only skull and partial leg bones preserved

B. burial on hardpan mixture of clay and sand

C. skull at 2.5 feet bs, artifacts from 28-31 inches bs

D. feet toward the west
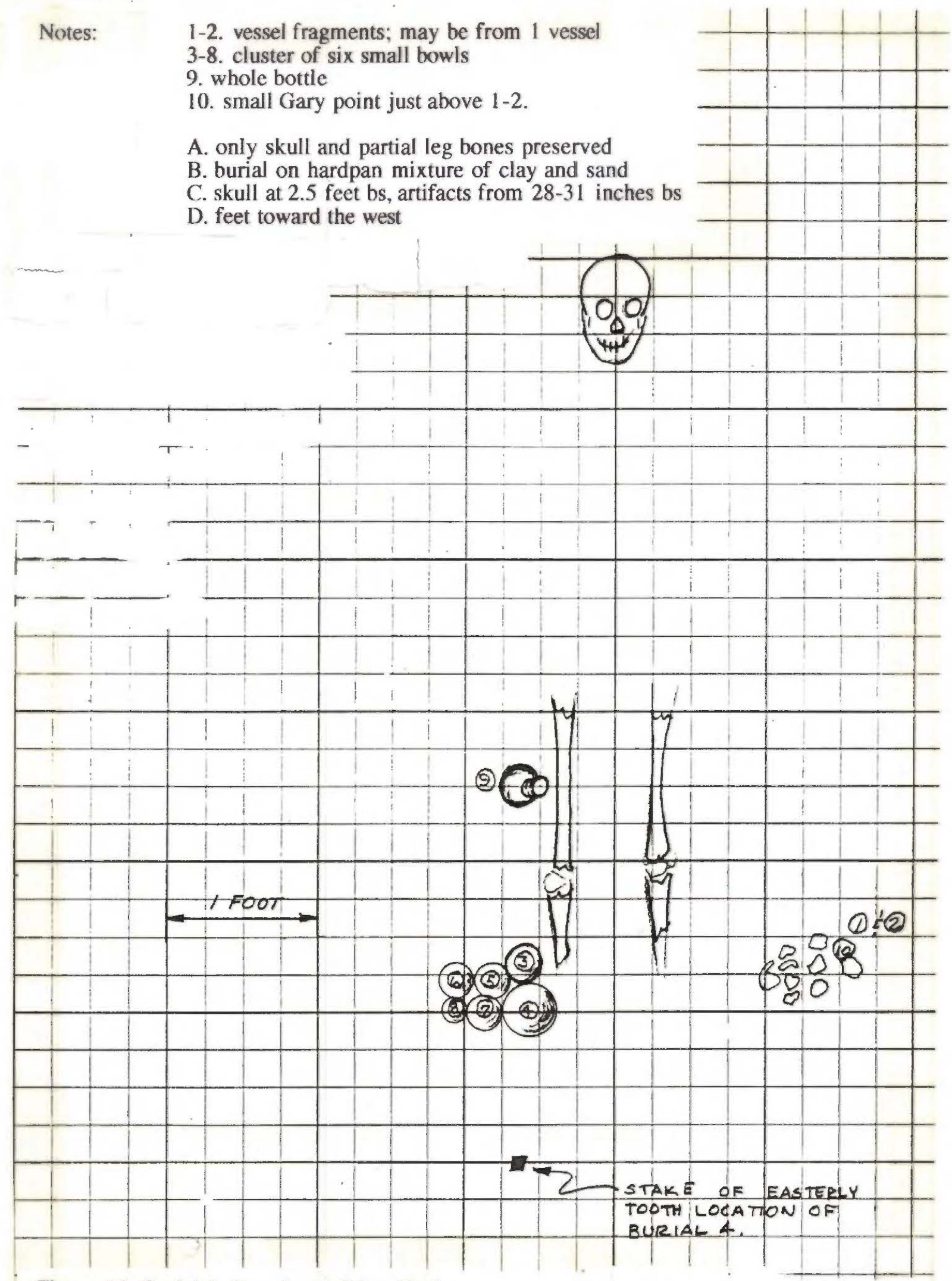

Figure 16. Burial 6, Graydon Adkins \#2 site. 


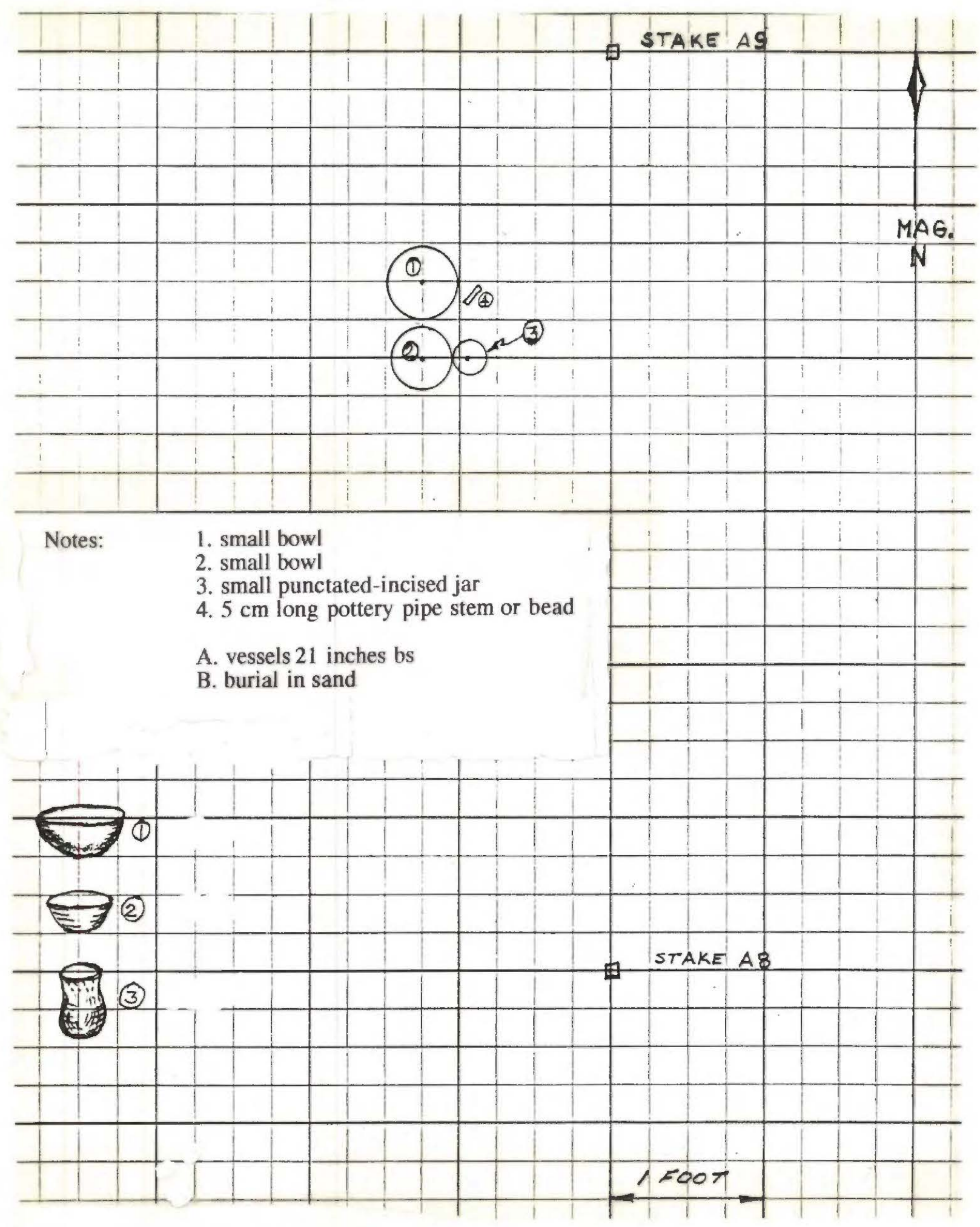

Figure 17. Burial 7, Graydon Adkins \#2 site. 


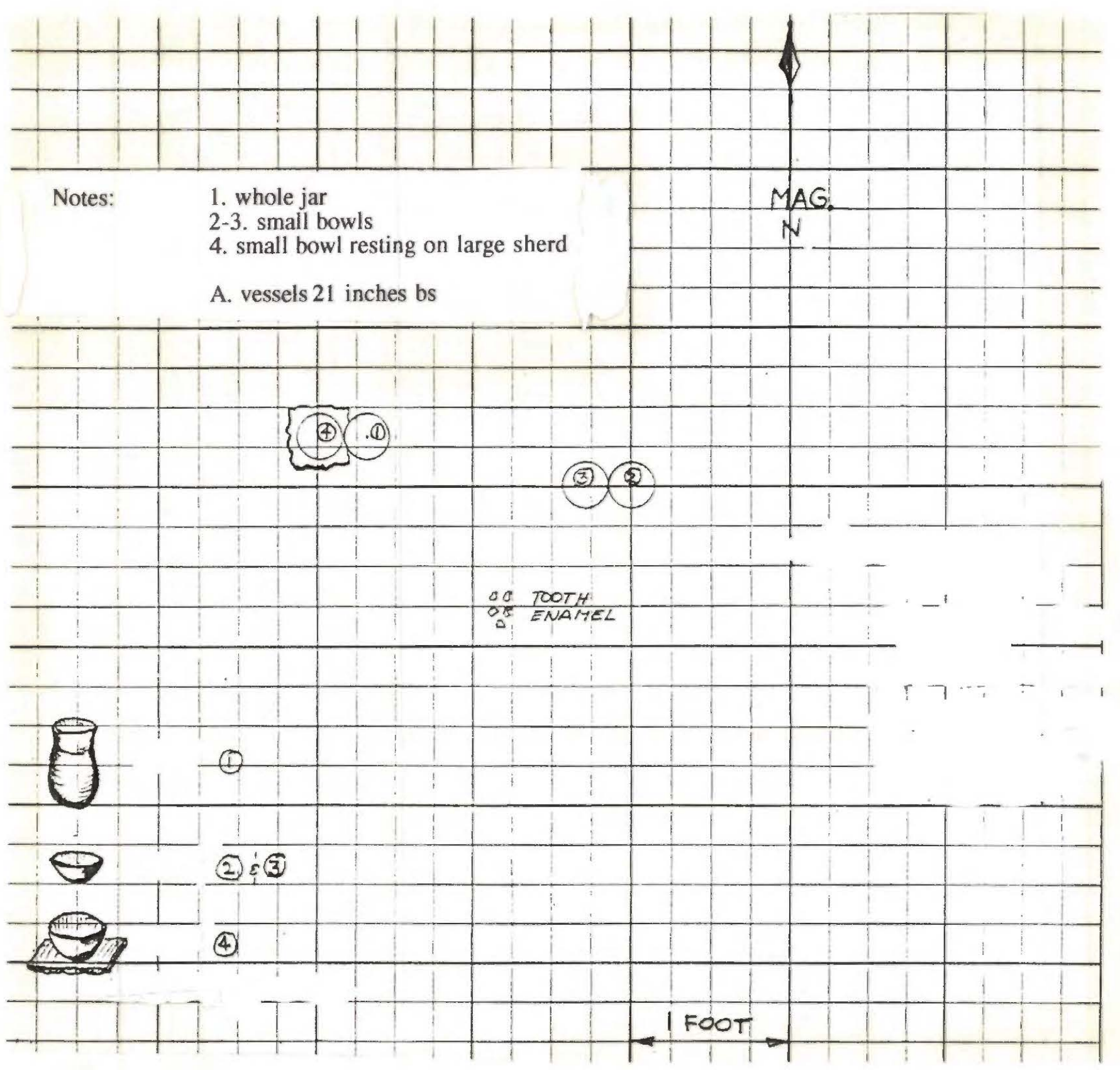

Figure 18. Burial 8, Graydon Adkins \#2 site. 


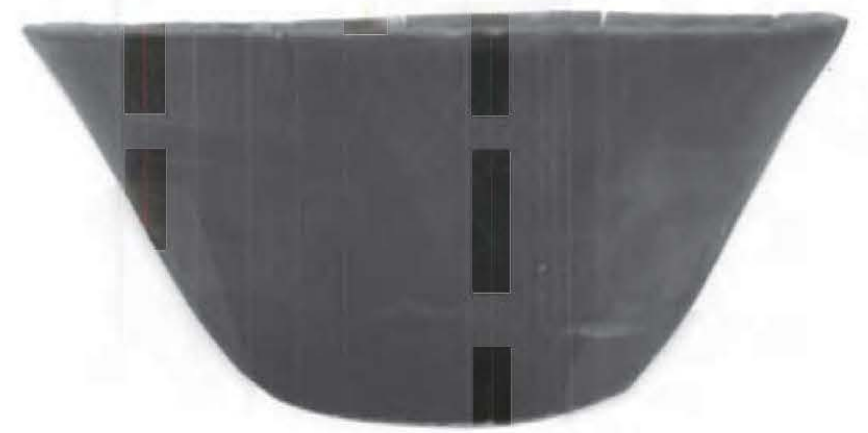

A

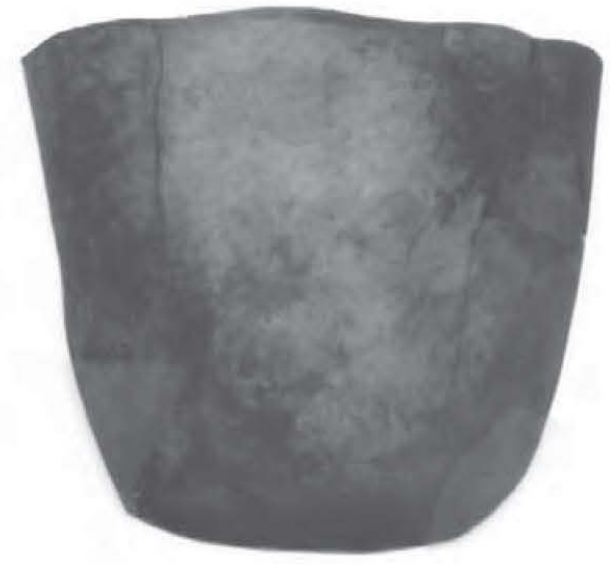

B

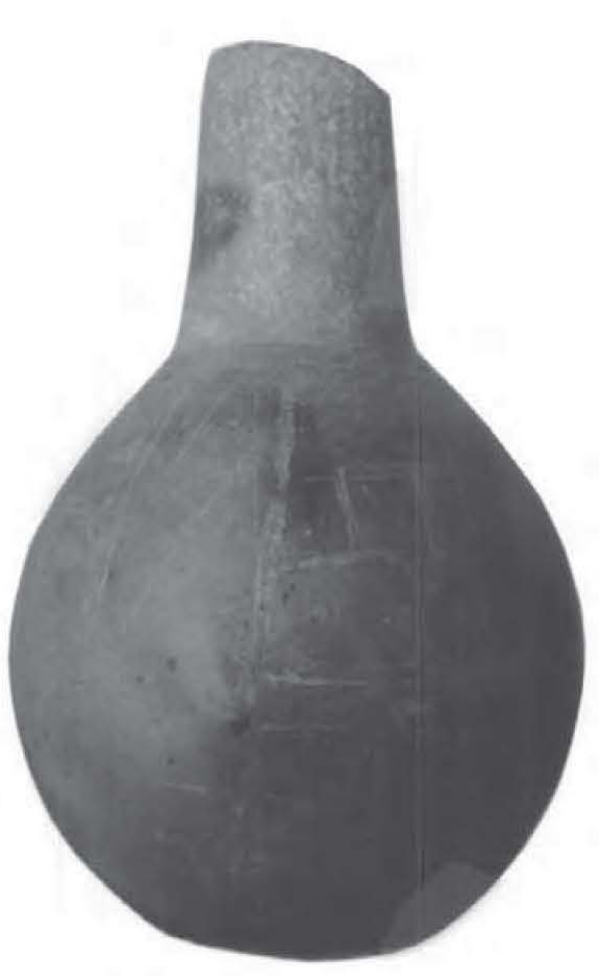

C

Figure 19. Ceramic Vessels from Burials 2, 4, and 5, Graydon Adkins \#2 site. 
is the absence of large cooking vessels and carinated bowls, and they each have stemmed arrow points (Figure 20). Decorated vessels are much more common in the Graydon Adkins \#1 assemblage than in the other sites. A cursory examination of the vessel designs suggests this site may belong to the Whelan phase.

\section{References Cited}

Turner, R. L., Jr.

1978 The Tuck Carpenter Site and Its Relation to Other Sites within the Titus Focus. Bulletin of the Texas Archeological Society 49:1-110. 


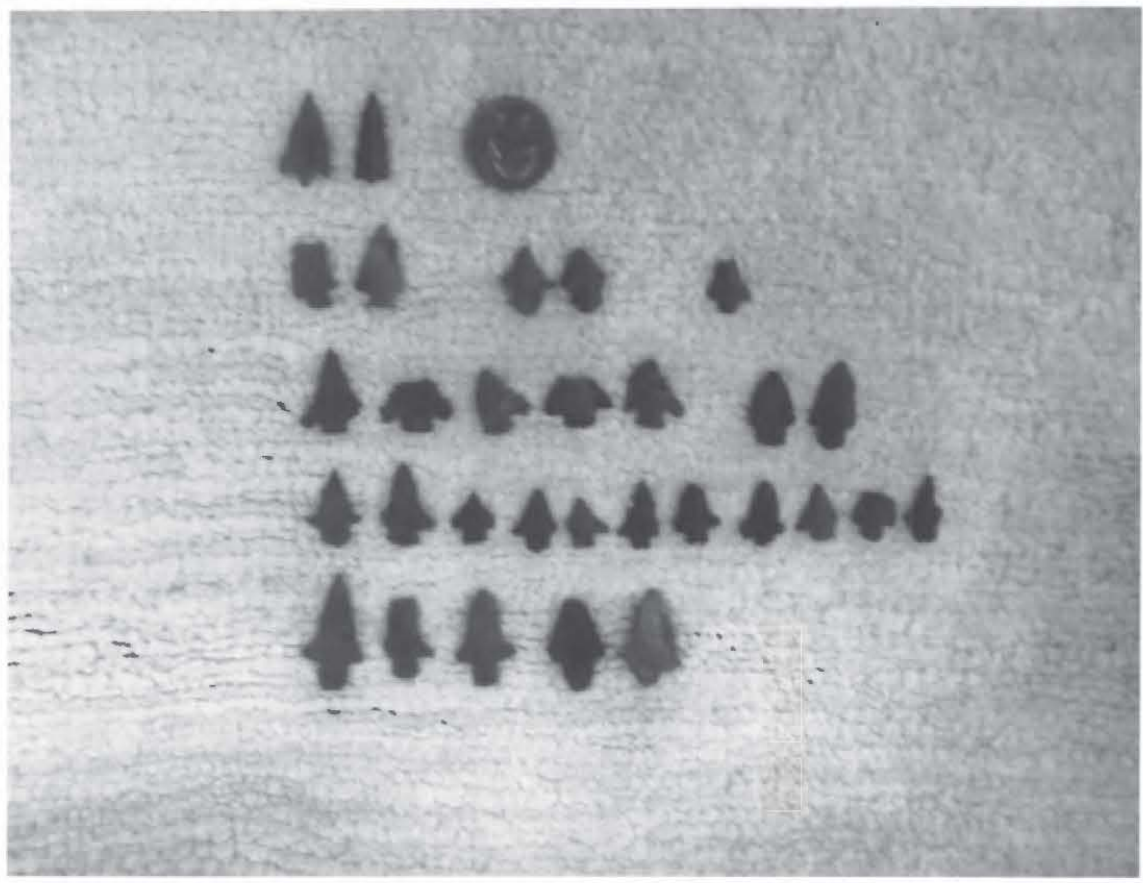

Figure 20. Stemmed Arrowpoints from the Harold Williams site. 